\title{
2016 Evaluation of Fair Plan 3: Outlook for Global Temperature Change throughout the 21 ${ }^{\text {st }}$ Century
}

\author{
Michael E. Schlesinger \\ Department of Atmospheric Sciences, University of Illinois at Urbana-Champaign, Urbana, IL, USA \\ Email: schlesin@aillinois.edu
}

How to cite this paper: Schlesinger, M.E. (2017) 2016 Evaluation of Fair Plan 3: Outlook for Global Temperature Change throughout the 21st Century. Journal of Environmental Protection, 8, 426-435. https://doi.org/10.4236/jep.2017.84031

Received: March 21, 2017

Accepted: April 23, 2017

Published: April 26, 2017

Copyright $\odot 2017$ by author and Scientific Research Publishing Inc. This work is licensed under the Creative Commons Attribution International License (CC BY 4.0).

http://creativecommons.org/licenses/by/4.0/

\begin{abstract}
In 2013, the author and colleagues made a projection of temperature departures (from the 1961-1990 average) throughout the remainder of the $21^{\text {st }}$ century due both to Humanity and Nature. Two scenarios of human-caused emissions of greenhouse gases and aerosol precursors were examined: (1) A reference scenario with no emissions reductions, and (2) our Fair Plan to Safeguard Earth's Climate which zeroes emissions from 2020 through 2100. Human-caused temperature changes from 1756 were calculated using an engineering-type Simple Climate Model. Temperature changes due to Nature were projected from our analyses of the observed temperature departures from 1850 through 2012. These natural changes were due to: (1) Three quasi-periodic oscillations (QPOs), each of which we fit with a sine wave to project into the future on a year-by-year basis; (2) Other QPOs that are too irregular to predict yearly, and (3) stochastic noise. We projected natural variations (2) and (3) by the $90 \%$ confidence interval of a Normal (Gaussian) probability density function, with zero mean and standard deviation of $0.08^{\circ} \mathrm{C}$. Here we add four more years of observed temperature departures to compare with our projections made in 2013. Each of the additional four temperature departure observations for 2013, 2014, 2015 and 2016 fits within the $90 \%$ envelop of temperature departures, thereby rendering our projection accurate to date. Most of the temperature changes during the 2012-2016 period were due to the annually unpredictable natural variability. This evaluation will be repeated quadrennially for the remainder of the author's life.
\end{abstract}

\section{Keywords}

Climate Change, Global Warming, Greenhouse-Gas Emissions, Mitigation

\section{Introduction}

In our 2013 paper, “A Fair Plan to Safeguard Earth's Climate: 3. Outlook for 
Global Temperature Change throughout the $21^{\text {st }}$ Century" [1], we projected the future change in global-mean near-surface air temperature through the $21^{\text {st }}$ century for two scenarios of future $\mathrm{CO}_{2}$ and other greenhouse-gas emissions, shown in Figure 1.

The Reference scenario is the Reference Concentration Pathway (RCP-8.5) scenario that was constructed at the Institute for Applied Systems Analysis in Austria [2] as the highest emission scenario for the fifth assessment report (AR5) [3] of the Intergovernmental Panel on Climate Change (IPCC). The RCP-8.5 scenario was based on the earlier A2 scenario of the IPCC Special Report on Emissions Scenarios [4], described as:

"The A2 storyline and scenario family describes a very heterogeneous world. The underlying theme is self-reliance and preservation of local identities. Fertility patterns across regions converge very slowly, which results in continuously increasing global population. Economic development is primarily regionally oriented and per capita economic growth and technological change are more fragmented and slower than in other storylines."

The author was a co-author of the 2000 SRES Report. Then he thought that the A2 scenario was highly unlikely. Regrettably, that seems wrong now.

The 8.5 of the RCP -8.5 scenario is the radiative forcing-the change in the net incoming radiation at the top of Earth's atmosphere-in $\mathrm{Wm}^{-2}$ in 2100. For comparison, a doubling of the pre-industrial $\mathrm{CO}_{2}$ concentration causes a radiative forcing of $3.7 \mathrm{~W} \cdot \mathrm{m}^{-2}$.

Figure 1 shows that the Reference $\mathrm{CO}_{2}$ emissions increase from 36.6 billion tonnes of $\mathrm{CO}_{2}$ per year (GtCO2/year) in 2010 to $106.7 \mathrm{GtCO} 2 /$ year in 2100 , remain constant to 2150 , and then decrease linearly in time (shown here only to 2200).

The Fair Plan emission scenario was constructed by us to satisfy three objectives:

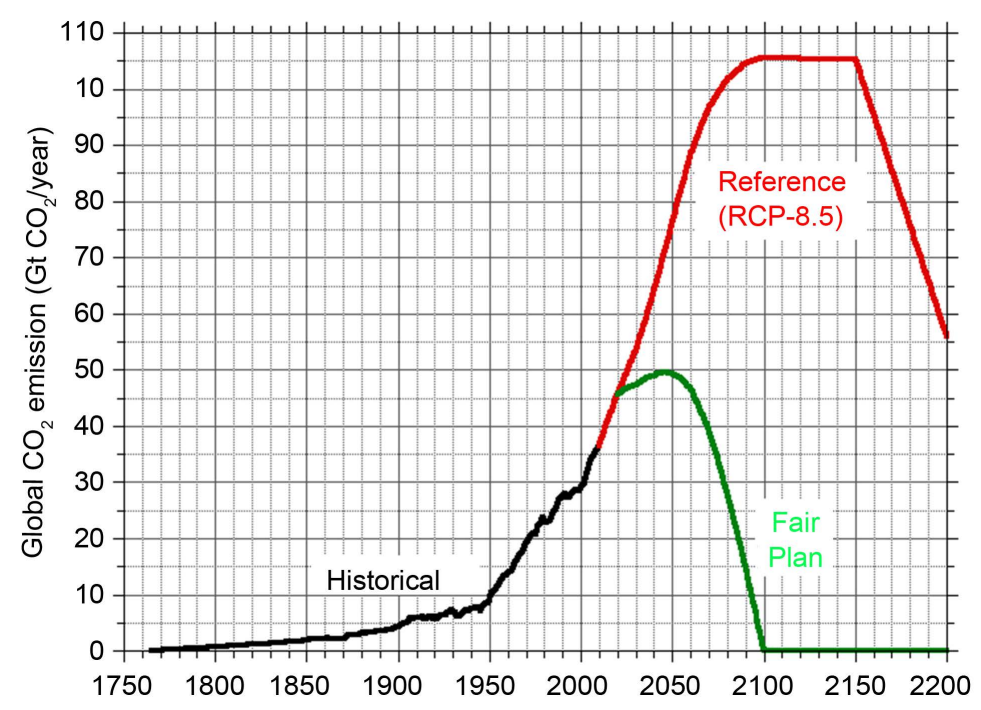

Figure 1. Historical (black curve) and future $\mathrm{CO}_{2}$ emissions for the Reference case (red curve) and the Fair Plan (green curve). 
Objective 1: The cumulative trade-adjusted $\mathrm{CO}_{2}$ emissions by the developing countries equal the cumulative trade-adjusted $\mathrm{CO}_{2}$ emissions by the developed countries. Trade-adjusted emissions mean the emissions incurred by country A to export goods and/or services to country B are debited to country B, not country A.

Objective 2: The maximum global warming above preindustrial temperature does not exceed the $2^{\circ} \mathrm{C}\left(3.6^{\circ} \mathrm{F}\right)$ chosen by the United Nations Framework Convention on Climate Change (UNFCCC) "to prevent dangerous anthropogenic interference with the climate system" [5].

Objective 3: The phaseout of $\mathrm{CO}_{2}$ and other greenhouse-gas emissions is begun as late as possible in the $21^{\text {st }}$ century and proceeds at the slowest possible pace, consistent with Objectives 1 and 2, to minimize the disruption of the global economy.

Figure 1 shows that the Fair Plan $\mathrm{CO}_{2}$ emissions increase from 45.6 GtCO2/year in 2020 to $49.5 \mathrm{GtCO} 2 /$ year in 2046 and then decrease to zero in 2100.

The $\mathrm{CO}_{2}$ concentration for the Reference and Fair Plan scenarios is shown in Figure 2 through the $22^{\text {nd }}$ century. The Reference $\mathrm{CO}_{2}$ concentration increases monotonically with time, reaching $1849 \mathrm{ppmv}$ in 2200, more than 6 times the pre-industrial $\mathrm{CO}_{2}$ concentration of $277 \mathrm{ppmv}$ in 1750.

The $\mathrm{CO}_{2}$ concentration for the Fair Plan rises to 612 ppmv in 2087, a bit more than twice the preindustrial $\mathrm{CO}_{2}$ concentration of $554 \mathrm{ppmv}$, and then decreases to 523 in 2200. (N.B. The calculations of the $\mathrm{CO}_{2}$ concentration were performed throughout the third millennium in "Fair Plan 7: Earth's Climate Future $=\mathrm{Hu}$ manity's Choice" [6].)

\section{Projection of Global Warming through the $21^{\text {st }}$ Century}

Here we discuss the calculation of temperature changes and departures due to

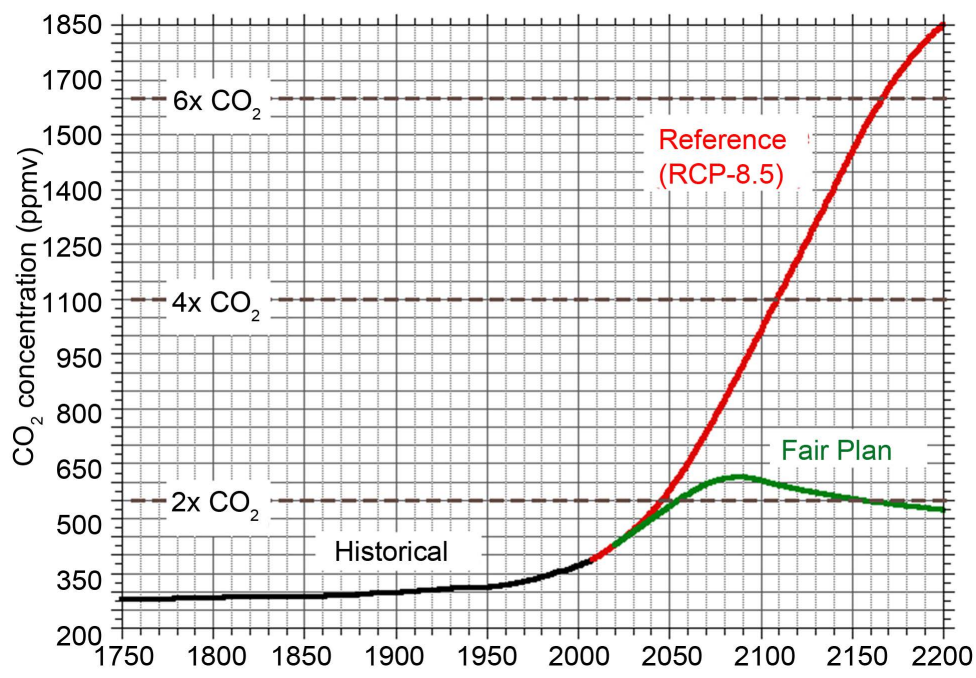

Figure 2. Historical (black curve) and future $\mathrm{CO}_{2}$ concentrations for the Reference case (red curve) and Fair Plan (green curve). Two, four and six times the preindustrial $\mathrm{CO}_{2}$ concentration are shown by the dashed brown lines. 
Humanity (Section 2.1) and Nature (Section 2.2), and the comparison thereof with the observed temperature departures from 1850 through 2012 (Section 2.3).

\subsection{Calculated Temperature Changes and Departures}

The change in global-mean near-surface air temperature from 1765 caused by humanity is calculated using the engineering-type Simple Climate Model (an energy-balance climate/upwelling-diffusion ocean model) created by the author in 1984 when he taught at the Institut d'Astronomie et de Geophysique G. Lemaitre, Universite Catholique de Louvain in Louvain-la-Neuve, Belgium. This model is described in "Modeling and Simulation of Climate and Climate Change" [7]. That model was combined with the CICERO model which calculates concentrations and radiative forcing from emissions [8]. The combined model includes 33 additional greenhouse gases, three aerosols, and three other radiative-forcing factors. These are listed in Table 4 of "Fair Plan 7: Earth's Climate Future $=$ Humanity's Choice" [6].

In "A Fair Plan to Safeguard Earth's Climate: 3. Outlook for Global Temperature Change Throughout the $21^{\text {st }}$ Century" [1], we calculated the change in global-mean near-surface air temperature from 1765 through 3000 for four climate sensitivities (the equilibrium Global Warming for a doubling of the pre-industrial $\mathrm{CO}_{2}$ concentration, $\Delta \mathrm{T}_{2 \mathrm{x}}$ ) estimated by us in "Causes of the Global Warming Observed Since the 19th Century" [9] for the HadCRU (start year, $\mathrm{y}_{\mathrm{o}}=1850$; $\left.\Delta \mathrm{T}_{2 \mathrm{x}}=1.61^{\circ} \mathrm{C}\right), \operatorname{NOAA}\left(\mathrm{y}_{\mathrm{o}}=1880 ; \Delta \mathrm{T}_{2 \mathrm{x}}=1.99^{\circ} \mathrm{C}\right)$, NASA $\left(\mathrm{y}_{\mathrm{o}}=1850 ; \Delta \mathrm{T}_{2 \mathrm{x}}=\right.$ $1.45^{\circ} \mathrm{C}$ and JMA (Japanese Meteorological Agency; $\mathrm{y}_{\mathrm{o}}=1893 ; \Delta \mathrm{T}_{2 \mathrm{x}}=2.01^{\circ} \mathrm{C}$ ) observed temperature datasets. Here we present only our HadCRU results (Figure 7(A) of "A Fair Plan to Safeguard Earth's Climate: 3. Outlook for Global Temperature Change throughout the $21^{\text {st }}$ Century" [1]) because $y_{o}=1850$ for HadCRU is the earliest of the four datasets. We converted the calculated temperature changes from 1765 to temperature departures from the 1961-1990 mean temperature to compare with the observed HadCRU temperature departures from the 1961-1990 mean temperature.

The calculated temperature changes through 2012 include the human-caused contributions due to the emission of greenhouse gases and aerosol precursors, and land-use changes. They also include variations in solar irradiance due to the 11-year sunspot cycle and the Maunder Minimum therein, and volcanoes. The simulated temperature changes from 2012 through year 3000, shown here only through 2100, include the human-caused contributions due to the emission of greenhouse gases and aerosol precursors for each scenario, and variations in solar irradiance due to the 11-year sunspot cycle.

\subsection{Natural Variability}

In addition to the human-caused change in global-mean near-surface air temperature, we also include the change therein due to natural variability, which we analyzed in our 2012 paper, "Causes of the Global Warming Observed Since the 19th Century" [9]. Figure 3, based on our follow-on paper, "A Simple Decon- 
struction of the HadCRU Global-Mean Near-Surface Temperature Observations" [10], shows the natural variability consists of: (1) several quasi-periodic oscillations (QPO's), and (2) random noise. Therein we represented the first three QPO's (O1, O2 \& O3 in Figure 3) by sine waves, with parameters shown in Table 1 op. cit.; and the other more irregular QPO's and noise by white noise, with a mean of zero and a standard deviation of $0.08^{\circ} \mathrm{C}$.

\subsection{Historical and Projected Temperature Departures}

Figure 4 presents the observed departures of the global-mean near-surface temperature from the 1961-1990 mean temperature from 1850 through 2012 for the HadCRU dataset (black line) used in "A Fair Plan to Safeguard Earth's Climate: 3. Outlook for Global Temperature Change throughout the $21^{\text {st }}$ Century" [1].

The solid orange line in Figure 4 shows the calculated temperature departures from 1756 through 2012 for the historical radiative forcing resulting from human activity, the Sun and volcanoes, plus the predictable natural variability, $\mathrm{O} 1+\mathrm{O} 2+\mathrm{O} 3$. The dashed orange lines show the $90 \%$ confidence interval of $\pm 0.18^{\circ} \mathrm{C}\left( \pm 0.32^{\circ} \mathrm{F}\right)$ for the calculated temperature departures plus the natural variability.

The solid red line in Figure 4 shows the calculated temperature departures from 2012 through 2100 for the radiative forcing resulting from the Reference scenario for human activity and the Sun, plus the predictable natural variability,

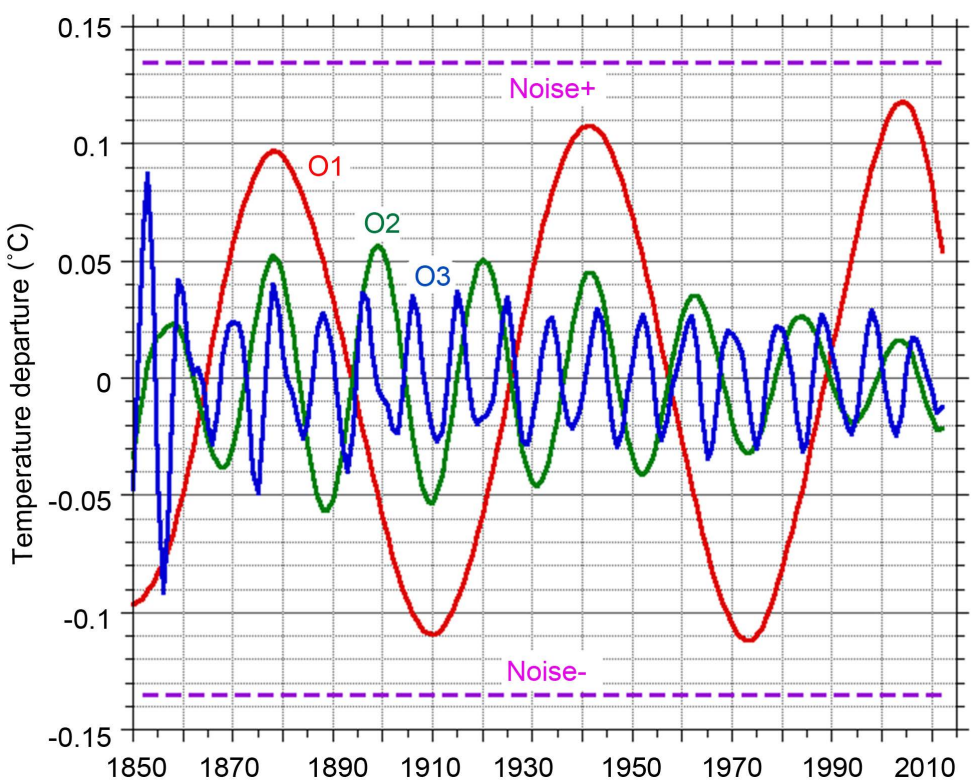

Figure 3. Components of natural variability in the HadCRU observed departures of global-mean near-surface Temperature from the 1961-1990 average, from 1850 through 2012, as analyzed in "Causes of the Global Warming Observed Since the 19th Century" [9] and "A Simple Deconstruction of the HadCRU Global-Mean Near-Surface Temperature Observations” [10]. Quasi-periodic oscillations $\mathrm{O} 1, \mathrm{O} 2$ and $\mathrm{O} 3$ are shown by the solid red, green and blues lines, respectively. The $90 \%$ confidence interval of the other QPO's and random noise are shown by the dashed purple lines. 


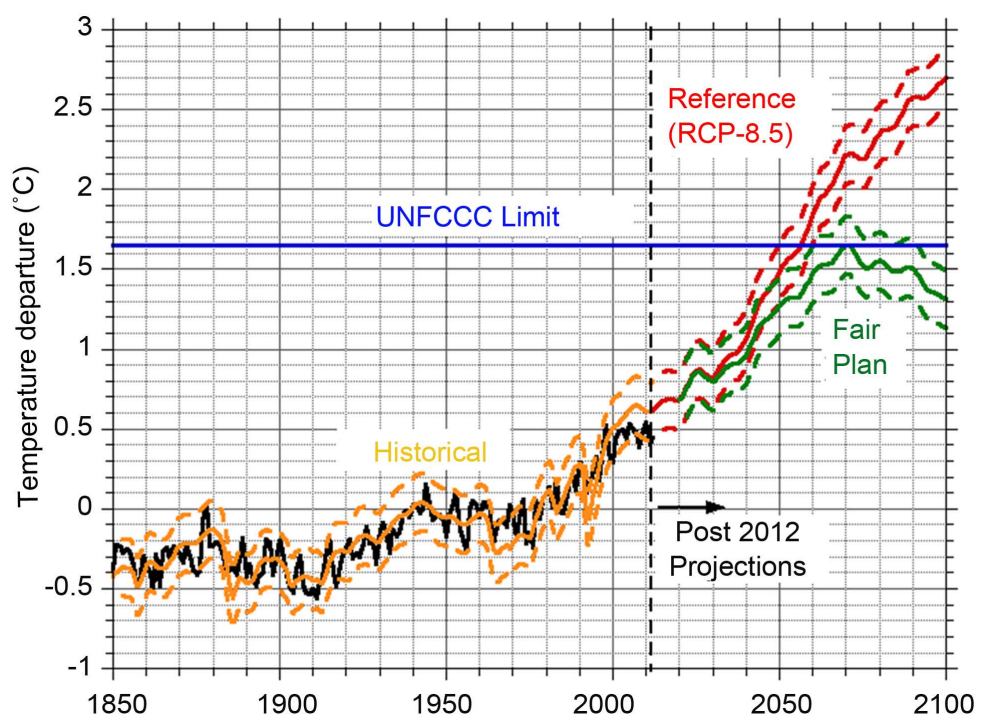

Figure 4. HadCRU observed departures of global-mean near-surface temperature from the 1961-1990 average through 2012 (solid black line) and projected post-2012 departures (to the right of the dashed vertical black line) for the Reference scenario (solid red line) and Fair Plan scenario (solid green line), together with the $90 \%$ confidence interval of the projections due to natural variability (dashed red and green lines). The UNFCCC global warming limit of $2^{\circ} \mathrm{C}$ from pre-industrial temperature, converted to temperature departure (dark blue line).

$\mathrm{O} 1+\mathrm{O} 2+\mathrm{O} 3$. The dashed red lines show the $90 \%$ confidence interval of $\pm 0.18^{\circ} \mathrm{C}$ $\left( \pm 0.32^{\circ} \mathrm{F}\right)$ for the calculated temperature departures plus the natural variability.

The solid green line in Figure 4 shows the calculated temperature departures from 2020 through 2100 for the radiative forcing resulting from the Fair Plan scenario for human activity and the Sun, plus the predictable natural variability, $\mathrm{O} 1+\mathrm{O} 2+\mathrm{O} 3$. The dashed green lines show the $90 \%$ confidence interval of $\pm 0.18^{\circ} \mathrm{C}\left( \pm 0.32^{\circ} \mathrm{F}\right)$ for the calculated temperature departures plus the natural variability.

Figure 4 shows that the human-caused global temperature departure for the Reference scenario, plus the external variability due to the sun and the internal variability due to the predictable QPO's, exceeds the UNFCCC temperature-departure limit of $1.65^{\circ} \mathrm{C}$ in 2057 , and reaches $2.70^{\circ} \mathrm{C}$ in 2100 .

In contrast, the global temperature departure for the Fair Plan, plus the external variability due to the sun and the internal variability due to the predictable QPO's, peaks at the UNFCCC limit (blue line) in 2082, and decreases thereafter.

It can be seen that the projected human-caused temperature departures plus external and predictable internal variability decrease in some years. Adding the $90 \%$ confidence interval of $\pm 0.18^{\circ} \mathrm{C}\left( \pm 0.32^{\circ} \mathrm{F}\right)$ for the unpredictable natural variability makes such interannual decreases all the more possible.

It is for this reason that we cautioned in our 2000 Causes paper [11]:

"Accordingly, it is prudent not to expect continued year-after-year warming in the near future and, in so doing, diminish concern about global warming should global cooling instead manifest itself again." 
Nonetheless, it is clear from both projections that the world will continue to warm due to human activities, throughout the $21^{\text {st }}$ century and beyond for the Reference scenario, and until the late $21^{\text {st }}$ century for the Fair Plan scenario.

\section{2016 Evaluation of Projected Temperature Departures}

The four additional observed temperature departures for 2013, 2014, 2015 and 2016 are shown by the light blue line in Figure 5. It can be seen that all of these four temperature departures lie within the $90 \%$ confidence interval for the projection for the Reference scenario. Note that the Fair Plan scenario begins in 2020, after the four new temperature observations. If the Fair Plan is implemented beginning in 2020, which seems increasingly unlikely now due to the climate-unfriendly policies of the new Trump administration in the United States [12] [13], it will not be possible to determine which Global Warming path the world will be on until about 2050, this due to the thermal inertia of the climate system.

Figure 6 shows an enlargement of Figure 5 from 2006 through 2016. Here it can be seen that the observed temperature departures for 2008 and 2011 lie outside the $90 \%$ confidence interval, below the 5 -percentile bound shown by the lower orange dashed curve. Of course, this can happen because 5 percent of the 1850 through 2012 observed temperature departures lie below the 5-percentile line. Nonetheless, all four of the new observational temperature departures lie within the $90 \%$ confidence interval. It is seen that the observed temperature departures increase for the four new years due to annually unpredictable natural variability.

\section{Discussion and Conclusion}

As I teach the students in my 100-level Climate and Global Change course at the

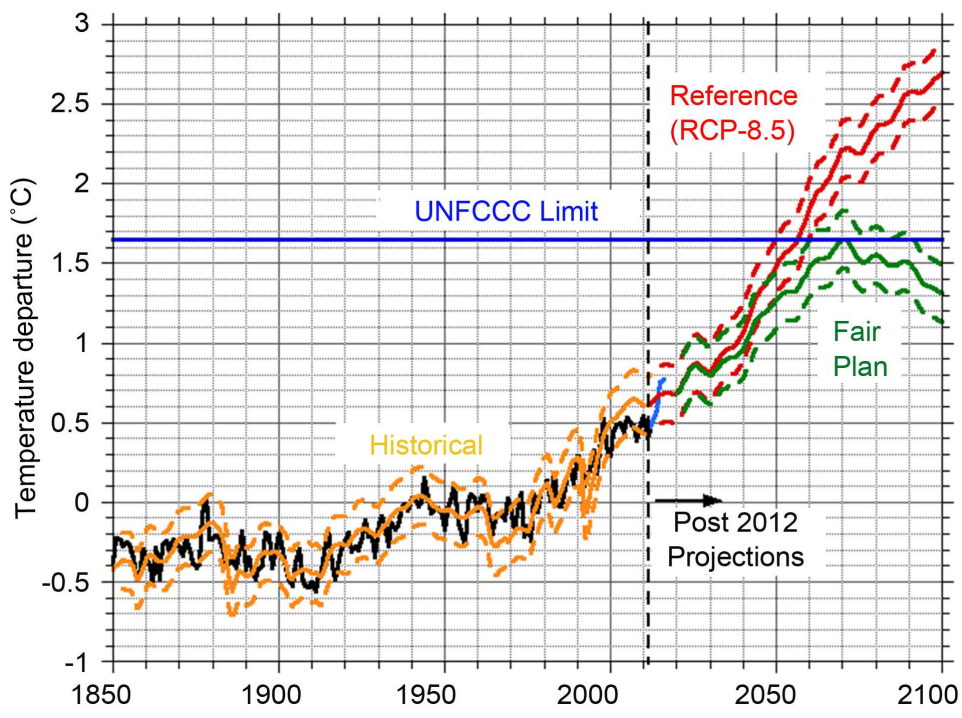

Figure 5. As in Figure 4, but with four additional observed temperature departures for 2013, 2014, 2015 and 2016 shown by the light blue line. 


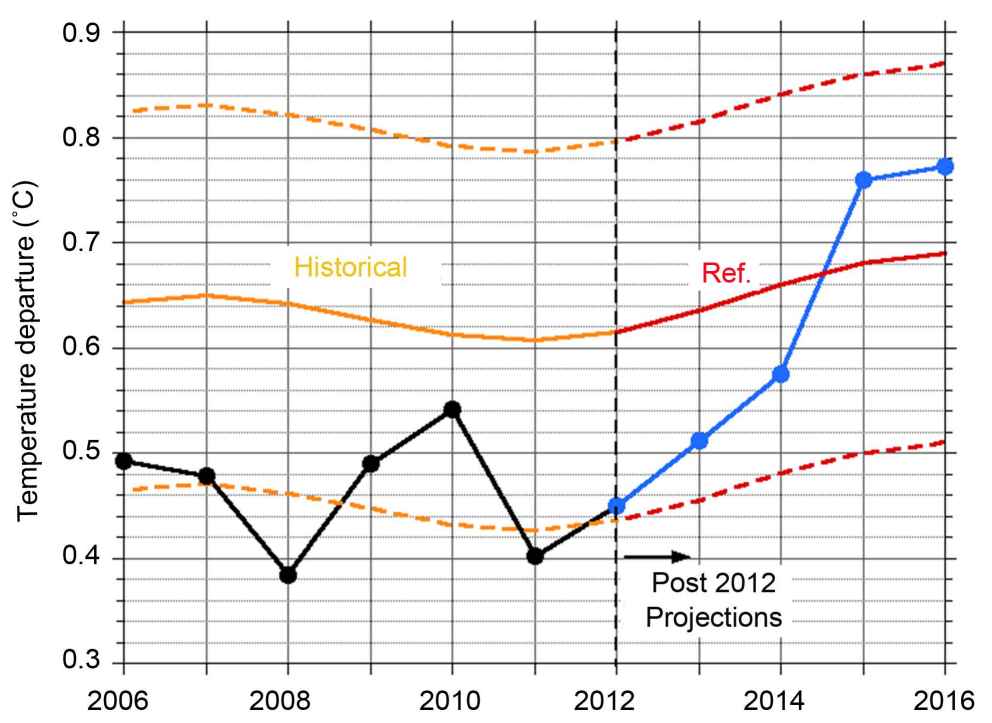

Figure 6. Enlargement of Figure 5 from 2006 through 2016.

University of Illinois at Urbana-Champaign, 21,000 years ago, where they now sit in my classroom, there was an ice sheet, the Laurentide ice sheet. Then there was so much ice on North America and western Europe-the Scandinavian ice sheet-that sea level was 133 meters (400 feet) below where it is now.

That ice is no longer on North America and western Europe because Earth's orbital conditions favorable for an ice age ended. The ice sheets on Greenland and Antarctica did not go away. Why? Because they are much closer to the North and South Poles, respectively, than were the ice sheets on North America and western Europe, and the Earth's temperature in the polar regions remained cold enough for the polar ice sheets to persist. This teaches us that Global Warming, in the past due to Mother Nature, but now and in the future, due to humanity, can cause ice sheets to disappear.

The Greenland and Antarctic ice sheets did not exist during the Late Eocene, 35 million years ago, when the $\mathrm{CO}_{2}$ concentration was $1250 \mathrm{ppmv}, 600 \mathrm{ppmv}$ less than the $1849 \mathrm{ppmv} \mathrm{CO}_{2}$ concentration in 2100 (Figure 2) should humanity not cease its $\mathrm{CO}_{2}$ emissions. This ending of the Greenland and Antarctic ice sheets would raise sea level by 73 meters (240 feet), thereby drowning many coastal cities around the world. Some of the coastal cities of the World that would be inundated by a sea-level rise of 66 meters (216 feet), based on a study by the National Geographic Society [14], are listed here from Table 3 of "Fair Plan 7: Earth's Climate Future = Humanity's Choice" [6]:

Cancún, Veracruz, Havana, Houston, New Orleans, Miami, Tampa, Charleston, Norfolk, Washington D.C., New York, Boston, San Diego, London, Brussels, Amsterdam, Copenhagen, Stockholm, Helsinki, St. Petersburg, Tallinn, Riga, Venice, Istanbul, Odessa, Baghdad, Doha, Dubai, Karachi, Mumbai (Bombay), Kolkata (Calcutta), Dhaka, Yangon (Rangoon), Bangkok, Kuala Lumpur, Jakarta, Singapore, Phnom Penh, Ho Chi Minh City, Manila, Hong Kong, Shanghai, Beijing, Seoul, Tokyo, Lima, Asuncion, Montevideo, Rio de Janeiro, 
Dakar, Freetown Monrovia, Lagos, Luanda, Maputo, Dar es Salaam, Perth, Adelaide, Melbourne, Sydney, Brisbane, Auckland, Wellington.

This drowning of coastal cities will cause hundreds of millions of people living there to migrate inland as Climate Refugees. This will cause enormous strife and conflict. For example, will India-a Hindu nation-accept Climate Refugees from neighboring Bangladesh-a low-lying, Muslim nation?

What should humanity do to prevent this climate catastrophe? Humanity is now on the Global-Warming Titanic. There is only so much time to steer a different course before it is too late to avoid the collision: the melting of Earth's remaining ice sheets.

In our next paper, "Fair Plan 10: Post-Trump Global-warming Mitigation", we shall explore this issue further. Stay tuned.

\section{References}

[1] Schlesinger, M.E., Lindner, D., Ring, M.J. and Cross, E.F. (2013) A Fair Plan to Safeguard Earth's Climate: 3. Outlook for Global Temperature Change throughout the 21st Century. Journal of Environmental Protection, 4, 653-664.

http://www.scirp.org/journal/Paperinformation.aspx?PaperID=33421 https://doi.org/10.4236/jep.2013.46075

[2] Riahi, K., Gruebler, A. and Nakicenovic, N. (2007) Scenarios of Long-Term Socio-Economic and Environmental Development under Climate Stabilization. Technological Forecasting and Social Change, 74, 887-935.

[3] Stocker, T.F., Qin, D., Plattner, G.-K., Tignor, M., Allen, S.K., Boschung, J., Nauels, A., Xia, Y., Bex, V. and Midgley, P.M. (2013) IPCC, Climate Change 2013: The Physical Science Basis. Contribution of Working Group I to the Fifth Assessment Report of the Intergovernmental Panel on Climate Change. Cambridge, UK and New York, USA, 1535p.

[4] Nakicenovic, N., et al. (2000) Special Report on Emissions Scenarios, a Special Report of the Intergovernmental Panel on Climate Change. Cambridge University Press, Cambridge, 570p.

[5] United Nations (2010) Report of the Conference of the Parties on its Sixteenth Session. Cancun, Mexico, 31p.

[6] Schlesinger, M.E., et al. (2015) Fair Plan 7: Earth's Climate Future = Humanity's Choice. Atmospheric and Climate Sciences, 5, 345-366.

http://www.scirp.org/Journal/PaperInformation.aspx?PaperID=58452 https://doi.org/10.4236/acs.2015.53027

[7] Schlesinger, M.E., Ring, M., Cross, E.F. and Lindner, D. (1997) Modeling and Simulation of Climate and Climate Change. In: Castagnoli, G.C. and Provenzale, A. Eds., Past and Present Variability of the Solar-Terrestrial System: Measurement, Data Analysis and Theoretical Models, Proceedings of the International School of Physics “Enrico Fermi” CXXXIII, IOS Press, Amsterdam, 389-429.

[8] Fuglesvedt, J.S. and Berntsen, T. (1999) A Simple Model for Scenario Studies of Changes in Climate, Version 1.0. CICERO, Oslo, 59p.

[9] Ring, M.J., Lindner, D., Cross, E.F., Schlesinger, M.E. (2012) Causes of the Global Warming Observed since the 19th Century. Atmospheric and Climate Sciences, 2, 401-415.

http://www.scirp.org/journal/PaperInformation.aspx?paperID=24283 https://doi.org/10.4236/acs.2012.24035 
[10] Schlesinger, M.E., Lindner, D., Ring, M.J. and Cross, E.F. (2013) A Simple Deconstruction of the HadCRU Global-Mean Near-Surface Temperature Observations. Atmospheric and Climate Sciences, 3, 353-359.

http://www.scirp.org/journal/Paperinformation.aspx?PaperID=34078 https://doi.org/10.4236/acs.2013.33036

[11] Andronova, N.G. and Schlesinger, M.E. (2000) Causes of Global Temperature Changes during the 19th and 20th Centuries. Geophysical Research Letters, 27, 2137-2140.

http://onlinelibrary.wiley.com/doi/10.1029/2000GL006109/epdf https://doi.org/10.1029/2000GL006109

[12] Mooney, C. (2017) Trump's Budget Would Torpedo Obama's Investments in Climate Change and Clean Energy. Washington Post, Washington D.C.

[13] Worland, J. (2017) President Trump's Proposed Budget Is a Blow to Fighting Climate Change. And It's Not Just the EPA.

http://time.com/4703569/trump-budget-epa-climate-change/

[14] National Geographic. (2014) If All the Ice Melted: Explore the World's New Coastlines If Sea Level Rises 216 Feet.

http://ngm.nationalgeographic.com/2013/09/rising-seas/if-ice-melted-map

\section{Submit or recommend next manuscript to SCIRP and we will provide best} service for you:

Accepting pre-submission inquiries through Email, Facebook, LinkedIn, Twitter, etc. A wide selection of journals (inclusive of 9 subjects, more than 200 journals)

Providing 24-hour high-quality service

User-friendly online submission system

Fair and swift peer-review system

Efficient typesetting and proofreading procedure

Display of the result of downloads and visits, as well as the number of cited articles

Maximum dissemination of your research work

Submit your manuscript at: http://papersubmission.scirp.org/

Or contact jep@scirp.org 